\title{
UJI EFEK ANALGESIK EKSTRAK DAUN BELUNTAS (Pluchea indica (L.) Less.) PADA MENCIT (Mus musculus)
}

\author{
${ }^{1}$ Venty Riani Sibarani \\ ${ }^{2}$ Pemsi Mona Wowor \\ ${ }^{2}$ Henoch Awaloei
}

\author{
${ }^{1}$ Kandidat Skripsi Fakultas Kedokteran Universitas Sam Ratulangi Manado \\ ${ }^{2}$ Bagian Farmakologi dan Terapi Fakultas Kedokteran Universitas Sam Ratulangi Manado \\ Email: ventysibarani09266@yahoo.com
}

\begin{abstract}
This research aimed to know whether or not the extract of marsh fleabane leaves possess an analgesic effect on mice. This research used experimental method, with the sample of 15 mice divided into 5 groups. The negative control group is given aquadest, the positive control group is given paracetamol, and 3 experimental group are given marsh fleabane leaves extract, each is given at dose $150 \mathrm{mg} / \mathrm{kgBB}, 300 \mathrm{mg} / \mathrm{kgBB}$, and $600 \mathrm{mg} / \mathrm{kgBB}$. The testing of analgesic effect is done by giving pain stimulation to the mice, by means of applying $55^{\circ} \mathrm{C}$ heat. Mice's response is observed is licking or flicking response. The observation is done for 1 minute. The observation is done before the administration of test substances, and then the observation is done on the $30^{\text {th }}, 60^{\text {th }}, 90^{\text {th }}$, and $120^{\text {th }}$ minute after the administration of test substances. The research result showed the amount of response of pain stimulation on the group is given marsh fleabane leaves extract start decrease on the $30^{\text {th }}$ minute and keep on giving effect on the $60^{\text {th }}$ minute. On the $90^{\text {th }}$ minute the analgesic effect start decrease, but still show analgesic effect. The extract of marsh fleabane leaves show analgesic effect, but the effect analgesic of marsh fleabane is lower than paracetamol.
\end{abstract}

Keywords: analgesic, extract of marsh fleabane leaves, heat stimulation.

\begin{abstract}
Abstrak: Penelitian ini bertujuan untuk mengetahui ada tidaknya efek analgesik dari ekstrak daun beluntas. Penelitian ini bersifat eksperimental dengan menggunakan 15 ekor mencit yang dibagi ke dalam 5 kelompok. Kelompok kontrol negatif diberikan aquades, kelompok kontrol positif diberikan parasetamol, dan 3 kelompok eksperimental diberikan ekstrak daun beluntas, masing-masing dengan dosis $150 \mathrm{mg} / \mathrm{kgBB}, 300 \mathrm{mg} / \mathrm{kgBB}$, dan $600 \mathrm{mg} / \mathrm{kgBB}$. Pengujian efek analgesik dilakukan dengan memberikan rangsangan nyeri pada hewan uji, berupa rangsangan panas dengan suhu $55^{\circ} \mathrm{C}$. Respon mencit yang diamati yaitu gerakan menjilat kaki dan atau melompat. Pengamatan dilakukan selama 1 menit. Pengamatan dilakukan sebelum pemberian zat uji, kemudian berturut-turut pada menit ke-30, 60, 90, dan 120 setelah pemberian zat uji. Hasil penelitian menunjukkan jumlah respon terhadap rangsang nyeri pada kelompok mencit yang diberi ekstrak daun beluntas mulai menurun pada menit ke-30 dan terus memberikan efek pada menit ke-60. Pada menit ke-90 efek analgesiknya mulai menurun, tetapi masih menunjukkan efek analgesik. Ekstrak daun beluntas menunjukkan adanya efek analgesik, namun efek analgesiknya lebih rendah dari parasetamol.
\end{abstract}

Kata kunci: analgesik, ekstrak daun beluntas, rangsang panas

Indonesia memiliki beraneka ragam tanaman dengan jumlah kurang lebih 30.000 spesies dan baru ditemukan 940 spesies yang diyakini oleh masyarakat dapat menyembuhkan penyakit, yang disebut sebagai tanaman berkhasiat obat. ${ }^{1}$ Masyarakat Indonesia telah lama menggunakan tanaman berkhasiat obat untuk 
menyembuhkan penyakit. Pengetahuan tentang mengolah tanaman berkhasiat obat telah diwariskan secara turun temurun dari satu generasi ke generasi berikutnya. ${ }^{2}$

Di sekitar pekarangan kita juga bisa ditemukan tanaman yang ternyata berkhasiat sebagai obat. Salah satu tanaman yang diyakini masyarakat berkhasiat obat yaitu tanaman beluntas (Pluchea indica (L.) Less.). ${ }^{3-6}$

Daun beluntas biasanya digunakan masyarakat untuk menghilangkan bau badan, meningkatkan nafsu makan, melancarkan pencernaan, mengatasi nyeri persendian, nyeri otot, nyeri saat menstruasi, menurunkan demam, mengeluarkan keringat, mengobati scabies, dan tuberkulosis (TBC) kelenjar getah bening. Akar beluntas berkhasiat sebagai penyegar tubuh, mengeluarkan keringat, dan mengatasi nyeri persendian. Selain itu daun beluntas juga sering dikonsumsi oleh masyarakat sebagai lalapan. Daun beluntas memiliki rasa yang agak pahit dan daun beluntas bila diremas mengeluarkan bau yang harum. ${ }^{3-6}$

Beberapa penelitian menunjukkan bahwa tanaman beluntas memiliki efek sebagai antioksidan, anti-inflamasi, anti-amuba, dan antimikroba. ${ }^{7,8}$ Di Indonesia, tanaman beluntas secara tradisional digunakan sebagai obat penghilang nyeri (analgesik). ${ }^{3-6}$ Untuk menghilangkan nyeri, daun beluntas atau akar beluntas sebanyak 10-15 gram direbus dengan air, lalu airnya diminum. ${ }^{3-5}$

Penggunaan tanaman berkhasiat obat merupakan hal yang baik bagi masyarakat karena mungkin memiliki efek samping yang relatif lebih sedikit dari pada obat sintetik, namun pemanfaatan tanaman sebagai ramuan obat untuk penyakit tertentu harus diteliti dan diuji secara ilmiah agar dapat dipertanggungjawabkan. ${ }^{9}$ Oleh karena itu, penulis tertarik untuk meneliti tentang efek analgesik dari daun beluntas.

\section{METODE PENELITIAN}

Penelitian ini menggunakan metode eksperimental yang dilakukan di Laboratorium Farmakologi dan Terapi Fakultas Kedokteran UNSRAT. Penelitian ini dilakukan dari bulan September 2012 sampai Januari 2013. Penelitian ini menggunakan mencit (Mus musculus) sebanyak 15 ekor sebagai hewan uji yang dibagi dalam 5 kelompok, yaitu kelompok kontrol negatif, kelompok kontrol positif, dan 3 kelompok eksperimental yang diberi ekstrak daun beluntas dengan dosis berbeda.

\section{Alat dan bahan}

Alat-alat yang digunakan dalam penelitian yaitu oven, blender, kain penyaring, kertas saring Whartman no. 1, cawan petri, timbangan analitik, batang pengaduk, lumpang, water bath, beaker glass, penghitung waktu, semprit injeksi 1 ml, dan NGT no. 3,5.

Bahan-bahan yang digunakan dalam penelitian yaitu daun beluntas sebanyak 1,3 kg yang diambil dari Ranotongkor Kecamatan Tombariri Kabupaten Minahasa, etanol 95\%, parasetamol sediaan tablet 500 mg, aquades, dan pelet.

\section{Prosedur penelitian}

Ada beberapa hal yang perlu disiapkan dan dilakukan dalam penelitian ini, seperti penyiapan hewan uji, pembuatan ekstrak daun beluntas, pengujian efek analgesik, dan lain-lain.

\section{Penyiapan hewan uji}

Penelitian ini menggunakan mencit betina sebagai hewan uji, yang dibagi secara acak ke dalam 5 kelompok dan masingmasing kelompok terdiri dari 3 ekor mencit. Kelompok I sebagai kontrol negatif, kelompok II sebagai kontrol positif., kelompok III, IV, dan V sebagai kelompok eksperimental yang diberi ekstrak daun beluntas dengan dosis 150 $\mathrm{mg} / \mathrm{kgBB}, \quad 300 \mathrm{mg} / \mathrm{kgBB}, \quad$ dan 600 $\mathrm{mg} / \mathrm{kgBB}$. Sebelum pengujian dilakukan, mencit dipuasakan selama \pm 11 jam kemudian ditimbang. Berat badan mencit yang digunakan berkisar 20-40 gram.

\section{Cara pembuatan ekstrak daun beluntas}

Daun beluntas diambil sebanyak 1,3 
kg. Daun diambil mulai daun ke-4 sampai ke-15 dari pucuk. Daun beluntas kemudian dicuci dengan air bersih, lalu ditiriskan. Lalu daun dikeringkan dalam oven pada suhu $37^{\circ} \mathrm{C}$ selama \pm 5 hari. Daun yang telah kering dihaluskan dengan blender sampai menjadi tepung. Tepung daun beluntas ditimbang sebanyak 228 gram, kemudian direndam dengan $750 \mathrm{ml}$ etanol 95\% selama 5 hari terlindung dari cahaya. Selama perendaman setiap hari dilakukan pengadukan selama 15 menit. Setelah direndam selama 5 hari, larutan tersebut disaring dengan kain penyaring. Hasilnya kemudian disaring lagi dengan kertas saring Whartman no. 1. Filtrat hasil penyaringan diletakkan dalam cawan petri untuk diuapkan dalam oven suhu $40^{\circ} \mathrm{C}$ sampai didapatkan ekstrak pekat.

\section{Penyiapan larutan ekstrak}

Bila berat badan rata-rata mencit 20 gr, maka jumlah ekstrak yang diberikan pada kelompok mencit yang diberi dosis 150 mg/kgBB yaitu 3 mg. Jumlah ekstrak yang diberikan pada kelompok mencit yang diberi dosis $300 \mathrm{mg} / \mathrm{kgBB}$ yaitu $6 \mathrm{mg}$, jumlah ekstrak yang diberikan pada kelompok mencit yang diberi dosis 600 $\mathrm{mg} / \mathrm{kgBB}$ yaitu $12 \mathrm{mg}$. Cara membuat larutan ekstrak untuk kelompok mencit yang diberi ekstrak $3 \mathrm{mg}$ yaitu larutkan ekstrak sebanyak $100 \mathrm{mg}$ dalam $10 \mathrm{ml}$ aquades, kelompok mencit yang diberi ekstrak $6 \mathrm{mg}$ yaitu larutkan ekstrak sebanyak $100 \mathrm{mg}$ dalam $5 \mathrm{ml}$ aquades, dan kelompok mencit yang diberi ekstrak 12 mg yaitu larutkan ekstrak sebanyak 100 mg dalam 2,5 ml aquades. Campur larutan hingga homogen, lalu ambil 0,3 ml larutan untuk diberukan pada kelompok hewan eksperimental.

\section{Penyiapan larutan obat pembanding}

Dosis parasetamol yang digunakan adalah $1000 \mathrm{mg} / 50 \mathrm{kgBB}$ per kali pemberian, maka perhitungan dosis untuk mencit dengan berat badan rata-rata 20 gr ialah: $(20 / 50000)$ x $1000=0,4$ mg. Penyiapan larutan pembanding dilakukan dengan cara menggerus tablet parasetamol $500 \mathrm{mg}$, lalu dimasukkan ke dalam gelas ukur yang berisi $50 \mathrm{ml}$ aquades, campur hingga homogen. Ambil 0,04 ml larutan lalu tambahkan dengan 0,26 ml aquades sehingga diperoleh $0,3 \mathrm{ml}$ larutan untuk diberikan kepada kelompok kontrol positif.

\section{Cara Pemberian Zat Uji}

Pemberian zat uji dilakukan per oral dengan menggunakan semprit $1 \mathrm{ml}$ dan NGT no. 3,5.

\section{Pengujian efek analgesik}

Masukkan beaker glass ke dalam water bath yang berisi air, kemudian water bath dipanaskan hingga suhu $55^{\circ} \mathrm{C}$. Setelah suhu mencapai $55^{\circ} \mathrm{C}$, mencit dimasukkan ke dalam beaker glass tersebut. Setelah mencit ada dalam beaker glass maka responnya diamati, yaitu berupa gerakan menjilat kaki dan atau melompat. Pengamatan dilakukan selama 1 menit. Kepada masing-masing kelompok mencit diberikan larutan ekstrak, larutan obat pembanding dan aquades sebagai kontrol negatif. Mencit lalu diistirahatkan untuk diamati kembali pada menit ke-30. Pengamatan dilakukan hingga menit ke-120, dengan interval waktu 30 menit untuk setiap pengamatan. Pengamatan dilakukan sebanyak 5 kali, yaitu: sebelum pemberian zat uji, menit ke-30, 60, 90, dan 120 setelah pemberian zat uji.

\section{Penyajian Analisis Data}

Data hasil pengamatan respon mencit akan diolah dengan dideskripsikan dan dihitung serta disajikan dalam bentuk tabel dan grafik.

\section{HASIL PENELITIAN}

Data di bawah ini merupakan data hasil pengamatan terhadap 5 kelompok hewan uji yang masing-masing kelompok terdiri dari 3 ekor mencit. 
Tabel 1. Hasil pengamatan respon kelompok kontrol negatif (aquades)

\begin{tabular}{|c|c|c|c|c|c|c|c|c|c|c|c|c|c|c|c|}
\hline \multirow{4}{*}{ Subjek } & \multicolumn{15}{|c|}{ Jumlah Respon Mencit } \\
\hline & \multirow{2}{*}{\multicolumn{3}{|c|}{$\begin{array}{l}\text { Sebelum } \\
\text { Perlakuan }\end{array}$}} & \multicolumn{12}{|c|}{ Setelah Perlakuan (Pemberian Aquades) } \\
\hline & & & & \multicolumn{3}{|c|}{30 menit } & \multicolumn{3}{|c|}{60 menit } & \multicolumn{3}{|c|}{90 menit } & \multicolumn{3}{|c|}{120 menit } \\
\hline & $\mathrm{L}$ & $\mathrm{J}$ & $\mathrm{T}$ & $\mathrm{L}$ & $\mathrm{J}$ & $\mathrm{T}$ & $\mathrm{L}$ & $\mathrm{J}$ & $\mathrm{T}$ & $\mathrm{L}$ & $\mathrm{J}$ & $\mathrm{T}$ & $\mathrm{L}$ & $\mathrm{J}$ & $\mathrm{T}$ \\
\hline A & - & 82 & 82 & - & 79 & 79 & - & 64 & 64 & - & 86 & 86 & - & 70 & 70 \\
\hline B & 4 & 29 & 33 & - & 25 & 25 & - & 25 & 25 & - & 30 & 30 & 1 & 27 & 28 \\
\hline $\mathrm{C}$ & - & 30 & 30 & 13 & - & 13 & 25 & - & 25 & 16 & - & 16 & 17 & - & 17 \\
\hline Jumlah & & & 145 & & & 117 & & & 114 & & & 132 & & & 115 \\
\hline Rata-rata & & & 48,3 & & & 39 & & & 38 & & & 44 & & & 38,3 \\
\hline
\end{tabular}

Ket.: $\mathrm{L}=$ Lompat, $\mathrm{J}=$ Jilat, $\mathrm{T}=$ Total. Pembulatan bilangan desimal: $<0,5=0$ dan $\geq 0,5=1$

Tabel 2. Hasil pengamatan respon kelompok kontrol positif (parasetamol)

\begin{tabular}{|c|c|c|c|c|c|c|c|c|c|c|c|c|c|c|c|}
\hline \multirow{4}{*}{ Subjek } & \multicolumn{15}{|c|}{ Jumlah Respon Mencit } \\
\hline & \multirow{2}{*}{\multicolumn{3}{|c|}{$\begin{array}{c}\text { Sebelum } \\
\text { Perlakuan }\end{array}$}} & \multicolumn{12}{|c|}{ Setelah Perlakuan (Pemberian Obat) } \\
\hline & & & & \multicolumn{3}{|c|}{30 menit } & \multicolumn{3}{|c|}{60 menit } & \multicolumn{3}{|c|}{90 menit } & \multicolumn{3}{|c|}{120 menit } \\
\hline & $\mathrm{L}$ & $\mathrm{J}$ & $\mathrm{T}$ & $\mathrm{L}$ & $\mathrm{J}$ & $\mathrm{T}$ & $\mathrm{L}$ & $\mathrm{J}$ & $\mathrm{T}$ & $\mathrm{L}$ & $\mathrm{J}$ & $\mathrm{T}$ & $\mathrm{L}$ & $\mathrm{J}$ & $\mathrm{T}$ \\
\hline A & - & 53 & 53 & 1 & 32 & 33 & 1 & 28 & 29 & - & 41 & 41 & - & 49 & 49 \\
\hline B & - & 52 & 52 & - & 16 & 16 & - & 4 & 4 & - & 15 & 15 & - & 15 & 15 \\
\hline $\mathrm{C}$ & - & 56 & 56 & - & 27 & 27 & - & 19 & 19 & - & 19 & 19 & - & 13 & 13 \\
\hline Jumlah & & & 161 & & & 76 & & & 52 & & & 75 & & & 77 \\
\hline $\begin{array}{l}\text { Rata- } \\
\text { rata }\end{array}$ & & & 53,7 & & & 25,3 & & & 17,3 & & & 25 & & & 25,7 \\
\hline
\end{tabular}

Ket.: $\mathrm{L}=$ Lompat, $\mathrm{J}=$ Jilat, $\mathrm{T}=$ Total. Pembulatan bilangan desimal: $<0,5=0$ dan $\geq 0,5=1$

Tabel 3. Hasil pengamatan respon kelompok mencit yang diberi ekstrak daun beluntas dosis 150 $\mathrm{mg} / \mathrm{kgBB}$

\begin{tabular}{|c|c|c|c|c|c|c|c|c|c|c|c|c|c|c|c|}
\hline \multirow{4}{*}{ Subjek } & \multicolumn{15}{|c|}{ Jumlah Respon Mencit } \\
\hline & \multirow{2}{*}{\multicolumn{3}{|c|}{$\begin{array}{c}\text { Sebelum } \\
\text { Perlakuan }\end{array}$}} & \multicolumn{12}{|c|}{ Setelah Perlakuan (Pemberian Ekstrak) } \\
\hline & & & & \multicolumn{3}{|c|}{30 menit } & \multicolumn{3}{|c|}{60 menit } & \multicolumn{3}{|c|}{90 menit } & \multicolumn{3}{|c|}{120 menit } \\
\hline & $\mathrm{L}$ & $\mathrm{J}$ & $\mathrm{T}$ & $\mathrm{L}$ & $\mathrm{J}$ & $\mathrm{T}$ & $\mathrm{L}$ & $\mathrm{J}$ & $\mathrm{T}$ & $\mathrm{L}$ & $\mathrm{J}$ & $\mathrm{T}$ & $\mathrm{L}$ & $\mathrm{J}$ & $\mathrm{T}$ \\
\hline A & - & 75 & 75 & - & 60 & 60 & - & 50 & 50 & - & 53 & 53 & - & 56 & 56 \\
\hline B & - & 50 & 50 & - & 48 & 48 & - & 40 & 40 & - & 47 & 47 & - & 60 & 60 \\
\hline $\mathrm{C}$ & - & 58 & 58 & - & 47 & 47 & - & 49 & 49 & - & 52 & 52 & - & 48 & 48 \\
\hline Jumlah & & & 183 & & & 155 & & & 139 & & & 152 & & & 164 \\
\hline Rata-rata & & & 61 & & & 51,7 & & & 46,3 & & & 50,7 & & & 54,7 \\
\hline
\end{tabular}

Ket.: $\mathrm{L}=$ Lompat, $\mathrm{J}=$ Jilat, $\mathrm{T}=$ Total. Pembulatan bilangan desimal: $<0,5=0$ dan $\geq 0,5=1$

Tabel 1 menunjukkan bahwa rata-rata jumlah respon mencit sebelum pemberian aquades sebanyak 48,3 kali (dibulatkan menjadi 48 kali). Pada menit ke-30 setelah pemberian aquades, rata-rata jumlah respon mencit menjadi 39 kali, pada menit ke-60 menjadi 38 kali, pada menit ke-90 menjadi 44 kali dan pada menit ke-120 menjadi 38,3 kali (dibulatkan menjadi 38 kali).

Tabel 2 menunjukkan bahwa rata-rata 
jumlah respon mencit sebelum pemberian obat sebanyak 53,7 kali (dibulatkan menjadi 54 kali). Pada menit ke-30 setelah pemberian obat, rata-rata jumlah respon menurun menjadi 25,3 kali (dibulatkan menjadi 25 kali), pada menit ke-60 menjadi 17,3 kali (dibulatkan menjadi 17 kali) sedangkan pada menit ke-90 meningkat menjadi 25 kali dan pada menit ke-120 menjadi 25,7 kali (dibulatkan menjadi 26 kali).

Tabel 3 menunjukkan bahwa rata-rata jumlah respon mencit sebelum pemberian ekstrak sebanyak 61 kali. Pada menit ke-30 setelah pemberian ekstrak, rata-rata jumlah respon menurun menjadi 51,7 kali (dibulatkan menjadi 52 kali), pada menit ke-60 menjadi 46,3 kali (dibulatkan menjadi 46 kali), pada menit ke-90 menjadi 50,7 kali (dibulatkan menjadi 51 kali) dan pada menit ke-120 menjadi 54,7 kali (dibulatkan menjadi 55 kali).

Tabel 4 menunjukkan bahwa rata-rata jumlah respon mencit sebelum pemberian ekstrak sebanyak 53 kali. Pada menit ke-30 setelah pemberian ekstrak, rata-rata jumlah respon menurun menjadi 29,7 kali (dibulatkan menjadi 30 kali), pada menit ke-60 menjadi 30 kali, pada menit ke-90 menjadi 36,3 kali (dibulatkan menjadi 36 kali) dan pada menit ke-120 menjadi 39,3 kali (dibulatkan menjadi 39 kali).

Tabel 5 menunjukkan bahwa rata-rata

Tabel 4. Hasil pengamatan respon kelompok mencit yang diberi ekstrak daun beluntas dosis 300 $\mathrm{mg} / \mathrm{kgBB}$

\begin{tabular}{|c|c|c|c|c|c|c|c|c|c|c|c|c|c|c|c|}
\hline \multirow{4}{*}{ Subjek } & \multicolumn{15}{|c|}{ Jumlah Respon Mencit } \\
\hline & \multirow{2}{*}{\multicolumn{3}{|c|}{$\begin{array}{c}\text { Sebelum } \\
\text { Perlakuan }\end{array}$}} & \multicolumn{12}{|c|}{ Setelah Perlakuan (Pemberian Ekstrak) } \\
\hline & & & & \multicolumn{3}{|c|}{30 menit } & \multicolumn{3}{|c|}{60 menit } & \multicolumn{3}{|c|}{90 menit } & \multicolumn{3}{|c|}{120 menit } \\
\hline & $\mathrm{L}$ & $\mathrm{J}$ & $\mathrm{T}$ & $\mathrm{L}$ & $\mathrm{J}$ & $\mathrm{T}$ & $\mathrm{L}$ & $\mathrm{J}$ & $\mathrm{T}$ & $\mathrm{L}$ & $\mathrm{J}$ & $\mathrm{T}$ & $\mathrm{L}$ & $\mathrm{J}$ & $\mathrm{T}$ \\
\hline A & - & 70 & 70 & - & 36 & 36 & - & 35 & 35 & - & 45 & 45 & - & 60 & 60 \\
\hline B & - & 42 & 42 & - & 26 & 26 & - & 15 & 15 & - & 30 & 30 & - & 30 & 30 \\
\hline $\mathrm{C}$ & - & 47 & 47 & - & 27 & 27 & - & 40 & 40 & - & 34 & 34 & - & 28 & 28 \\
\hline Jumlah & & & 159 & & & 89 & & & 90 & & & 109 & & & 118 \\
\hline $\begin{array}{l}\text { Rata- } \\
\text { rata }\end{array}$ & & & 53 & & & 29,7 & & & 30 & & & 36,3 & & & 39,3 \\
\hline
\end{tabular}

Ket.: $\mathrm{L}=$ Lompat, $\mathrm{J}=$ Jilat, $\mathrm{T}=$ Total. Pembulatan bilangan desimal: $<0,5=0$ dan $\geq 0,5=1$

Tabel 5. Hasil pengamatan respon kelompok mencit yang diberi ekstrak daun beluntas dosis 600 $\mathrm{mg} / \mathrm{kgBB}$

\begin{tabular}{|c|c|c|c|c|c|c|c|c|c|c|c|c|c|c|c|}
\hline \multirow{4}{*}{ Subjek } & \multicolumn{15}{|c|}{ Jumlah Respon Mencit } \\
\hline & \multirow{2}{*}{\multicolumn{3}{|c|}{$\begin{array}{c}\text { Sebelum } \\
\text { Perlakuan }\end{array}$}} & \multicolumn{12}{|c|}{ Setelah Perlakuan (Pemberian Ekstrak) } \\
\hline & & & & \multicolumn{3}{|c|}{30 menit } & \multicolumn{3}{|c|}{60 menit } & \multicolumn{3}{|c|}{90 menit } & \multicolumn{3}{|c|}{120 menit } \\
\hline & $\mathrm{L}$ & $\mathrm{J}$ & $\mathrm{T}$ & $\mathrm{L}$ & $\mathrm{J}$ & $\mathrm{T}$ & $\mathrm{L}$ & $\mathrm{J}$ & $\mathrm{T}$ & $\mathrm{L}$ & $\mathrm{J}$ & $\mathrm{T}$ & $\mathrm{L}$ & $\mathrm{J}$ & $\mathrm{T}$ \\
\hline A & - & 53 & 53 & - & 31 & 31 & - & 35 & 35 & - & 28 & 28 & - & 32 & 32 \\
\hline B & - & 23 & 23 & - & 17 & 17 & - & 23 & 23 & - & 28 & 28 & - & 30 & 30 \\
\hline $\mathrm{C}$ & - & 62 & 62 & - & 40 & 40 & - & 35 & 35 & - & 45 & 45 & - & 55 & 55 \\
\hline Jumlah & & & 138 & & & 88 & & & 93 & & & 101 & & & 117 \\
\hline Rata-rata & & & 46 & & & 29,3 & & & 31 & & & 33,7 & & & 39 \\
\hline
\end{tabular}

Ket.: $\mathrm{L}=$ Lompat, $\mathrm{J}=$ Jilat, $\mathrm{T}=$ Total. Pembulatan bilangan desimal: $<0,5=0$ dan $\geq 0,5=1$ 


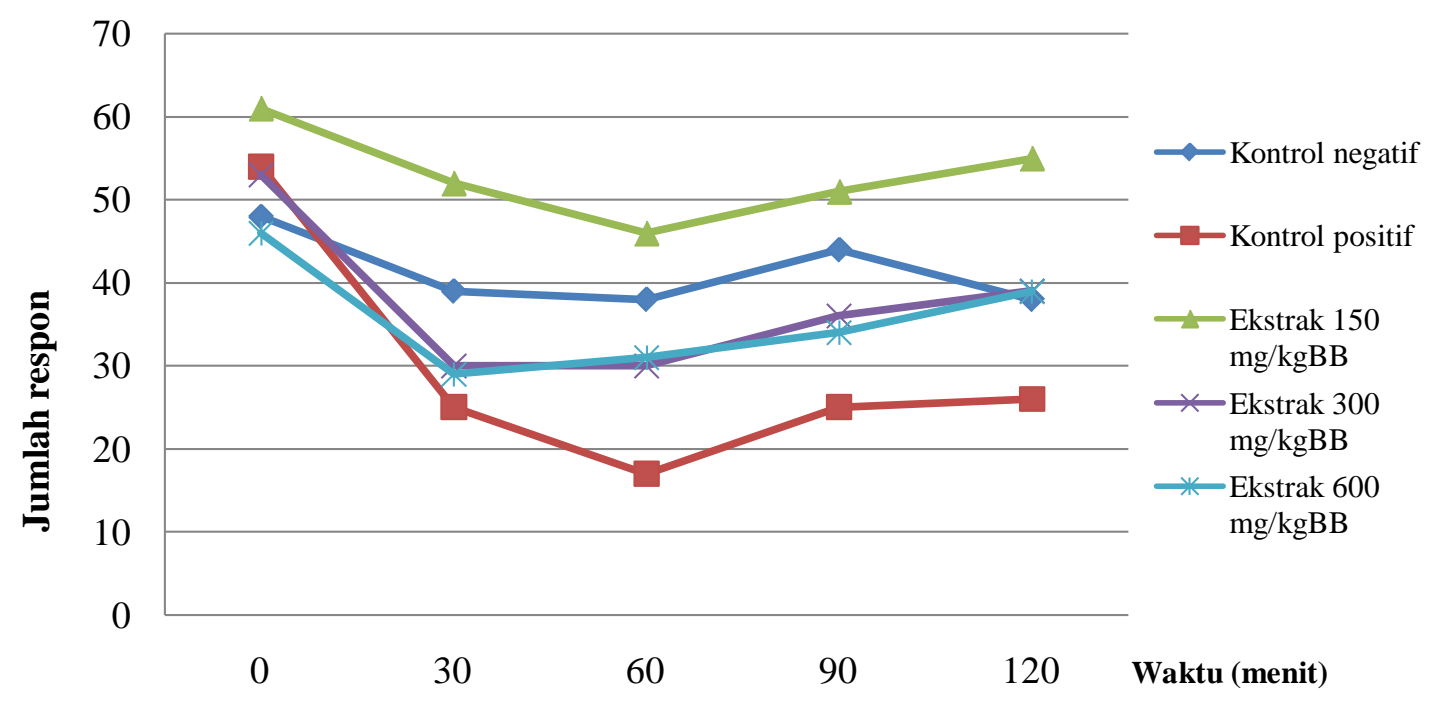

Gambar 1. Grafik rata-rata jumlah respon mencit

jumlah respon mencit sebelum pemberian ekstrak sebanyak 46 kali. Pada menit ke-30 setelah pemberian ekstrak, rata-rata jumlah respon menurun menjadi 29,3 kali (dibulatkan menjadi 29 kali), pada menit ke-60 menjadi 31 kali, pada menit ke-90 menjadi 33,7 kali (dibulatkan menjadi 34 kali) dan pada menit ke-120 menjadi 39 kali.

Pada gambar di bawah ini akan disajikan nilai rata-rata respon kelompok kontrol negatif, kelompok kontrol positif, dan kelompok eksperimental dalam bentuk grafik.

\section{BAHASAN}

Penelitian ini dilakukan untuk mengetahui ada tidaknya efek analgesik dari ekstrak daun beluntas dengan menggunakan metode rangsang panas (hot plate method) yang diuji pada mencit. Rangsangan yang diberikan pada hewan uji yaitu berupa rangsangan panas dengan suhu $55^{\circ} \mathrm{C}$. Respon mencit yang dinilai berupa gerakan menjilat kaki dan atau melompat. Efek analgesik dapat ditunjukkan dengan berkurangnya jumlah respon mencit.

Hasil pengujian pada kelompok eksperimental (ekstrak daun beluntas) yang diberi dosis berbeda, menunjukkan terjadi penurunan respon rata-rata hewan uji terhadap rangsangan nyeri. Hal ini menunjukkan bahwa ekstrak daun beluntas memiliki efek analgesik. Efek analgesik dari ekstrak daun beluntas ini diduga karena peran flavonoid yang terkandung dalam daun beluntas. Hasil penelitian yang dilakukan Owoyele dkk membuktikan bahwa kandungan flavonoid pada daun kirinyuh (Chromolaena odorata) memiliki efek analgesik ${ }^{10}$, tetapi apakah kandungan flavonoid pada daun beluntas dan daun kirinyuh adalah sama atau beda, perlu dilakukan penelitian lebih lanjut. Selain flavonoid, efek analgesik dari daun beluntas juga mungkin disebabkan oleh kandungan kimia lainnya. Oleh karena itu, perlu dilakukan penelitian lebih lanjut mengenai kandungan kimia lain yang berperan sebagai analgesik dan bagaimana mekanisme kerjanya.

Efek analgesik ekstrak daun beluntas mulai terlihat pada menit ke-30 dan terus memberikan efek pada menit ke-60. Pada menit ke-90 efek analgesiknya mulai menurun, tetapi masih menunjukkan efek analgesik. Pada grafik rata-rata jumlah respon mencit menunjukkan bahwa kuatnya efek analgesik dari kelompok mencit yang diberi ekstrak dosis $300 \mathrm{mg} / \mathrm{kgBB}$ dan 600 mg/kgBB tidak jauh berbeda. Hal ini menunjukkan dosis $300 \mathrm{mg} / \mathrm{kgBB}$ merupakan dosis maksimum karena pada dosis tersebut sudah mencapai kadar terapeutik maksimum. Bila dibandingkan dengan kelompok kontrol positif yang diberi parasetamol, efek analgesik dari ekstrak 
daun beluntas lebih rendah dari yang lebih banyak.

parasetamol.

Berdasarkan hasil yang didapat melalui pengujian pada kelompok kontrol positif yang diberi parasetamol, menunjukkan terjadi penurunan respon rata-rata hewan uji terhadap rangsangan nyeri. Efek analgesik dari kelompok kontrol positif mulai terlihat pada menit ke-30 dan mencapai tingkat maksimal pada menit ke60. Pada menit ke-90 efek analgesiknya sudah mulai menurun, tetapi masih menunjukkan efek analgesik. Diketahui bahwa parasetamol mencapai kadar puncak dalam plasma dalam waktu 30-60 menit dan memiliki waktu paruh $1-3$ jam, ${ }^{11,12}$ hal ini dapat menunjukkan adanya hubungan antara efek obat dengan kadar obat dalam plasma.

Pada kelompok kontrol negatif yang diberikan aquades, terlihat bahwa respon rata-rata hewan uji terhadap rangsangan nyeri sebelum pemberian aquades sebanyak 48 kali. Setelah pemberian aquades, berturut-turut pada menit ke-30, 60, 90, dan 120 menjadi 39 kali, 38 kali, 44 kali, dan 38 kali. Rata-rata jumlah respon mencit antara sebelum dan setelah pemberian aquades, ada yang naik dan ada yang turun. Hal ini diduga terjadi karena hewan uji yang digunakan belum mencapai galur murni.

\section{SIMPULAN}

Pada penelitian ini didapatkan bahwa ekstrak daun beluntas menunjukkan adanya efek analgesik pada mencit, namun efek analgesik ekstrak daun beluntas lebih rendah dari parasetamol.

\section{SARAN}

Perlu dilakukan penelitian lebih lanjut untuk identifikasi kandungan kimia yang berkhasiat sebagai analgesik pada daun beluntas, juga perlu dilakukan penelitian lebih lanjut untuk mengetahui mekanisme kerja analgesik ekstrak daun beluntas dan penelitian efek analgesik ekstrak daun beluntas dengan menggunakan hewan uji

\section{UCAPAN TERIMA KASIH}

Ucapan terima kasih disampaikan pada dr. C. Mambo, MSc, dr. J. Wuisan, MS, SpFK, dan semua pihak yang baik secara langsung maupun tidak langsung telah menumbuhkan ide atau gagasan dalam pemikiran penulis sehingga dapat menyelesaikan artikel ini.

\section{DAFTAR PUSTAKA}

1. Sukandar EY. Tren dan Paradigma Dunia Farmasi Industri-Klinik Teknologi Kesehatan. Disampaikan dalam orasi ilmiah Dies Natalis ITB ke 45 [homepage on the Internet]. Nodate [Cited 2012 Sep 13]. Available from: http://itb.ac.id/focus/ focus_file/orasi-ilmiah-dies-45.pdf

2. Sari LORK. Pemanfaatan Obat Tradisional dengan Pertimbangan Manfaat dan Keamanannya. Majalah Ilmu Kefarmasian [serial online]. 2006 [cited 2012 Sep 13];3:1-7. Available from: http://jurnal.farmasi.ui.ac.id/pdf/2006/v03 n01/lusia0301.pdf

3. Dalimartha S. Atlas Tumbuhan Obat Indonesia Jilid $1 . \quad$ Jakarta: Trubus Agriwidya, 1999; p.18-21.

4. Sentra informasi IPTEK. Tanaman Obat Indonesia [homepage on the Internet]. Nodate [cited 2012 Sep 15]. Available from: Available from: http://www.iptek.net.id/ind/pd_tanobat/vie w.php?mnu=2\&id=26.

5. Hartati S. Tanaman Hias Berkhasiat Obat. Bogor: IPB Press, 2011; p.9-10.

6. Andarwulan $N$, Batari $R$, Sandrasari DA, Bolling B, Wijaya H. Flavonoid Content and Antioxidant Activity of Vegetables from Indonesia. Food Chemistry [serial online]. 2010 [cited 2012 Sep 7]; 121:1231-35. Available from: http://seafast.ipb.ac.id/publication/journal/ 10-flavonoid-content-and-antioxidant-ofvegetables-from-Indonesia.pdf

7. Srisook K, Buapool D, Boonbai $R$, Simmasut P, Charoensuk Y, Srisook E. Antioxidant and Anti-inflammatory Activities of Hot Water Extract from Pluchea indica Less. Herbal Tea. Journal of Medicinal Plants Research [serial 
online]. 2012 [cited 2012 Sep 7]; 6(23):4077-81. Available from: http://www.academicjournals.org/JMPR

8. Roslida AH, Erazuliana AK, Zuraini A. Anti-inflammatory and Anti-nociceptive Activities of The Ethanolic Extract of Pluchea Indica (L) Less Leaf. Pharmacologyonline [serial online]. 2008 [cited 2012 Sep 7]; 2: 349-60. Available from: http://pharmacologyonline.silae.it/ files/archives/2008/vol2/31_Hamid.pdf

9. Thomas ANS. Tanaman Obat Tradisional 2: Pendahuluan [monograph online]. Yogyakarta: Kanisius, 2007; p.9-10. [cited 2012 Oct 28]. Availabel from: http://books.google.co.id/books?id=IKKIg dfhRzIC\&pg=PA7\&lpg $=$ PA7\&dq=tanama $\mathrm{n}+$ obat+tradisional +2+thomas+ans+penda huluan\&source $=$ bl\&ots=JH4nxXVV9N\&s ig=LLD-8g9hHeDLxjO_EgNF3P9OdM\&hl=id\&sa=X\&ei=5haNUJWmO c3yrQeBiYCQAw\&ved=0CC8Q6AEwA $\mathrm{w} \# \mathrm{v}=$ onepage $\& \mathrm{q}=\operatorname{tanaman} \% 20 \mathrm{obat} \% 20 \mathrm{tr}$ adisional\%202\%20thomas\%20ans\%20pen dahuluan \&f=false
10. Owoyele BV, Oguntoye SO, Dare K, Ogunbiyi BA, Aruboula EA, Soladoye AO. Analgesic, Anti-inflammatory and Antipyretic Activities from Flavonoid Fractions of Chromolaena odorata. Journal of Medicinal Plants Research [serial online]. 2008 [cited 2012 Des 26]; 2(9):219-25. Available from: http://www.unilorin.edu.ng/publications/o guntoyeso/scan0010.pdf

11. Wilmana PF, Gan S. Analgesikantipiretik, analgesik anti-inflamasi nonsteroid, dan obat gangguan sendi lainnya. Dalam: Gunawan SG, Setiabudy R, Nafrialdi, Elysabeth, editor. Farmakologi dan Terapi (Edisi Kelima). Jakarta: Departemen Farmakologi dan Terapeutik Fakultas Kedokteran Universitas Indonesia, 2008; p.230-46.

12. Furst DE, Ulrich RW. Obat antiinflamasi nonsteroid; obat antireumatik pemodifikasi penyakit, analgesik nonopioid, \& obat yang digunakan pada gout. Dalam: Katzung BG, editor. Farmakologi Dasar \& Klinik (Edisi Ke-10). Jakarta: EGC, 2011; p.589-635. 